\title{
Watching of Scary TV Shows by Children and Youth, Identification With Characters, and Resulting Fears and Nightmares
}

\author{
Gila Cohen Zilka ${ }^{1} \&$ Chen Goldberg ${ }^{2}$ \\ ${ }^{1}$ Bar-Ilan University; Achva Academic College, Israel \\ ${ }^{2}$ University of Haifa, Israel \\ Correspondence: Gila Cohen Zilka, Bar-Ilan University, Achva Academic College, Israel
}

Received: September 29, 2020 Accepted: October 21, 2020 Online Published: November 23, 2020

doi:10.5539/res.v13n1p1

URL: https://doi.org/10.5539/res.v13n1p1

\begin{abstract}
The identification of children and adolescents with characters from the television programs they watch is not limited to the time when they view the program. The connection with the characters continues across the use of various digital means and in various realms of the children's lives. The purpose of the present study was to examine the connections between patterns of use of various media, the degree of identification with characters from the programs watched, and the fears and nightmares experienced by the children after watching these programs. This is a mixed-method study. Two hundred ninety-six Israeli children and adolescents participated in the study; 45 children and adolescents among those who completed questionnaires were interviewed. The data were collected in 2017-2018. The data revealed that negative identification with the show characters was higher among children than in adolescents. Positive identification with the characters was higher among viewers of scary programs, among those who suffered from nightmares and fears, and among those who perceived the characters and plot as realistic. It was found that interest in programs involving tension, drama, and action increases the risk of nightmares and fears after watching these programs.
\end{abstract}

Keywords: viewing habits, TV programs, identification, wellbeing, television characters

\section{Introduction}

The identification of children and adolescents with characters from the television programs they watch is not limited to the time of viewing the shows. Children and adolescents search the Internet for content related to the programs and the characters, join interest groups that discuss television programs and characters on social networks, and encounter these characters in other areas, such as marketed products related to television shows and characters, costumes of characters, items of clothing similar to those worn be the characters, etc. Characters from television shows are featured on various digital media and in different areas of the children's lives. In this study we examined the connections between patterns of use of various media, the degree of identification with characters from the programs watched, and the fears and nightmares that follow the watching of these programs.

\section{The Media: A Part of the Children and Youth Environment}

Children today are exposed to a large selection of sources and channels of information. Many studies have shown that the media is playing an increasingly important role in children's lives (Byron, 2008; Livingstone et al., 2012; Livingstone et al., 2014; Ofcom, 2006; Taylor \& Kitter, 2010; Zilka, 2014, 2016a, 2016b). Researchers (Atwal et al., 2003; Comstock \& Scharrer, 2007; Gatfield \& Millwood-Hargrave, 2003; Holbert \& Stephenson, 2003; Livingstone, 2008, 2007; Millwood-Hargrave, 2007; Millwood-Hargrave \& Livingstone, 2006, 2009) have argued that because the media is part of our living environment, its influence in shaping the personality of a child lies in its interaction with other environmental factors, which affect each other in different ways. Researchers (Leung, 2013; McQuail, 2010; West \& Turner, 2007; Zilka, 2014, 2017, 2018a, 2018b, 2018c) have found that media consumers are rational, thinking persons who choose from a variety of media, decide to what they will be exposed, and shape their consumption habits according to their needs. For example, when children watch a program seeped in violence, it is necessary to find out what is the children's need, what is their reason for viewing violent content. The children must be offered an alternative option to the partial and at times negative solution they discover in the various media. Extensive viewing of violent content may create the impression in children that the world is violent and thus exacerbate their problem.

\section{Identification With Characters}

Television is a narrative medium that tells stories, in which characters act. The degree of identification with TV 
characters allows vicarious experience. Bandura (2001) argued that because indirect experiences of this kind are an important tool for social learning, identifying with characters allows the learning of negative and positive behaviors. Not every role model produces identification, and without identification, there is little chance of adoption and imitation of the character's behavior. In addition to the immediate behavioral effects of identification with TV characters, watching programs involves psychological processes that affect the consolidation of identity in the long term, not only immediately. Researchers (Bandura, 1971, 1986, 2001; Cole \& Leeds, 1999; Hough \& Erwin, 2010; Livingston \& Das, 2010; Morgan \& Shanahan, 2010; Rideout et al., 2010; Vandewater et al., 2006; Wilson, 2011; Zilka, 2014; Zilka \& Romi, 2018) have claimed that television presents a wide range of role models and offers children and adolescents an opportunity to try out and compare alternate identities. In this way, television offers a rich variety of characters to children as role models, and exposes them to characters to which they are unlikely to have been exposed face-to-face in real life. Television characters and imagery are particularly powerful because of the visual nature of the medium, and therefore, characters on screen, their appearance and behavior, become real. The mechanism of identification with television characters is part of the process by which children can evaluate the behaviors of characters, choose behaviors, and integrate them into their own lives. Children and adolescents play with toys and use TV-related brands, repeat the expressions the characters use, dress like the characters, etc. Negative identification refers to violent behavior of the character, harm caused to other characters, threats, etc. Positive identification refers to the desire of the viewer to be similar to the character, to be the friend of the character when the viewer feels that the character is sociable, and when the character's behavior contributes to a positive atmosphere of the show. The choice of television characters to identify with is not only a function of the traits of the character but also of those of the viewers. For example, Eyal and Rubin (2010) found that violent teenagers tended to identify with characters perceived as violent. The identification of children with television characters does not occur in a social void. TV programs are part of the life environment of children and adolescents, and their influence on shaping the personality and identity of the latter lies in the interaction with other environmental factors.

\section{The Connection Between Watching TV Shows and Violence}

Researchers (Bandura, 1965; Cline et al., 1973; Huesmann, Moise-Titus et al., 2003; Millwood-Hargrave \& Livingstone, 2006, 2009) investigated the relationship between TV viewing and violence through the lens of the desensitization theory (2003). Desensitization theory argues that repeated exposure to violence may suppress the natural negative responses to violence, and viewers may lose their natural sensitivity to violence and their capacity for empathy. Viewing can lead to identification with violent characters, justification of the violent acts of characters, and a perception of violent scenarios as real. Watching violence increases fears and nightmares in viewers, and may distort the construction of reality by children and adolescents. Studies have attempted to find a causal link between viewing violent content and subsequent aggression. Researchers in these studies focused on three harmful effects of violence on television: increased anti-social behavior, including emulated aggression seen on TV or negative interactions with others; reduction of sensitivity to violence and perception of violent behavior as normative and socially acceptable; and increasing the viewers' fear of becoming victims of violence. The abovementioned researchers found a connection between watching violence on TV programs and accepting violent behavior in others, as well as an exaggerated perception of the rate of violence in society. No causal relation has been established, however, between viewing of violence in TV programs and changes in behavior and perception. Researchers (Bandura, 1965; Cline et al., 1973; Huesmann et al., 2003; Millwood-Hargrave \& Livingstone, 2006, 2009) agree that viewing violence in TV programs is one of many factors that contribute to aggression, antisocial attitudes, and violence in children and adolescents. It also transpires that the effect of violence on viewers is related to the context in which it is presented, and the identification of the viewer with a character. In addition, significant differences were found between viewing audiences, stemming from their age, gender, marital status, and more.

This study examined the connections between negative and positive identification with the characters, criticism of the characters, self-image and anger reaction, background characteristics, habits, preferences, and types of programs, key factors affecting interest in programs, and patterns of viewing scary programs.

The research question was: What characterizes the connections between patterns of use of various media, watching scary TV programs, identifying with characters, and fears and nightmares resulting from watching, in children and adolescents?

\section{Method}

This was a mixed-method study. Forty-five of the participating children and adolescents who completed questionnaires were interviewed. Data collection was carried out in 2017-2018. Analysis of the statistical data is based on Beavers, Lounsbury, Richards, Huck, Skolits, and Esquivel (2013), and on Brown (2009). The content analysis is based on Adler and Adler (2008), Atkinson and Delamont (2006), and Hammersley (2008). 


\section{Sample}

After organizing and eliminating records in which one or more of the data items were missing, a sample of 296 respondents was obtained: $57 \%$ girls and $43 \%$ boys; $30.7 \%$ of the respondents were children aged 12 or younger, and the remaining $69 \%$ were adolescents. The socioeconomic situation of $60.8 \%$ of the respondents was average or worse; the rest $(39.2 \%)$ reported that their socioeconomic situation was better than average.

Table 1. Demographic characteristics of the sample

\begin{tabular}{|c|c|c|c|}
\hline Parameter & & Respondents & $\%$ \\
\hline \multicolumn{2}{|c|}{ Age } & \multicolumn{2}{|c|}{$\begin{array}{c}M=13.8[7.0,18.0] \\
S D=2.8\end{array}$} \\
\hline \multirow{2}{*}{ Gender } & Boy & 126 & $42.6 \%$ \\
\hline & Girl & 170 & $57.4 \%$ \\
\hline \multirow{2}{*}{ Age group } & Children & 91 & $30.7 \%$ \\
\hline & Adolescents & 205 & $69.3 \%$ \\
\hline \multirow{3}{*}{$\begin{array}{l}\text { Marital status of } \\
\text { parents }\end{array}$} & Married & 280 & $94.7 \%$ \\
\hline & Other & 14 & $4.7 \%$ \\
\hline & Unanswered & 2 & $0.7 \%$ \\
\hline \multirow{5}{*}{$\begin{array}{l}\text { Economic } \\
\text { situation }\end{array}$} & Well below average & 6 & $2.0 \%$ \\
\hline & Below average & 6 & $11.5 \%$ \\
\hline & Average & 140 & $47.3 \%$ \\
\hline & Above average & 108 & $36.5 \%$ \\
\hline & Well above average & 8 & $2.7 \%$ \\
\hline \multicolumn{2}{|c|}{ Number of rooms in the domicile } & \multicolumn{2}{|c|}{$\begin{array}{c}M=4.3[2.0,9.0] \\
S D=1.2\end{array}$} \\
\hline \multicolumn{2}{|c|}{ Number of siblings } & \multicolumn{2}{|c|}{$\begin{array}{c}M=2.8[0.0,23.0] \\
S D=2.3\end{array}$} \\
\hline
\end{tabular}

\section{Research Tools}

- Socio-demographic and socioeconomic questionnaire: age, gender, country of birth, sector, marital status of the parents, number of siblings, parents' occupation, type of household, number of rooms, socioeconomic situation.

- The Rogers self-image questionnaire (1967). The questionnaire is composed of ten statements, and respondents rank the appropriate answer on a 4-poiont scale ranging from 1=Don't agree at all to 4=Agree very much. For example: Overall, I am satisfied with myself. Sometimes I think I'm not good at all. I feel that I have some good qualities. I would like to have more self-respect. I adopt a positive attitude toward myself. Average $=$ 3.05 , standard deviation $=0.44$, reliability $($ Cronbach $\alpha)=0.81$.

- Questionnaire about attitudes toward identification with characters, based on the questionnaire by Block (1995). The questionnaire includes 51 statements divided into three parts (negative identification, positive identification, and attitudes toward the character). Items were rated on a 6-point scale ranging from $1=$ Not at all to $6=$ Yes, quite). Principal factor analysis with Varimax rotation of the solution, followed by ordering of the solution (Brown, 2009; Beavers et al., 2013), indicated the presence of three factors.

a. Index of positive identification with the character, 17 items; average $=4.58$, standard deviation $=1.38$, and reliability (Cronbach's $\alpha$ ) $=0.94$. Sample questions: How much do you want to be like the character? Do you identify with the character's personality? How much would you like to be the character's best friend? To what extent do you think the character is a good person? To what extent do you think the character is a sociable person? To what extent do you think the character's behavior is justified? How much does the character contribute to the positive atmosphere of the program? To what extent do you think it is right to behave the way the character does? To what extent does the character create a negative atmosphere? How much do you admire the character? How much did you feel critical of the character? To what extent did you think the character should behave differently? 
How much do you identify with the character? If I were in the character's place, would I behave in the same way? How much criticism do you have of how the character behaves? How much do you want to be the character? How much do you identify with the character's behavior?

b. Index of negative identification with the character, 19 items; average $=2.8$, standard deviation $=1.56$, and reliability (Cronbach's $\alpha$ ) $=0.96$. Respondents were asked to rate how the following behaviors describe the character in the TV program they love, for example: pushing, hitting, or kicking other characters in the program; gossiping or spreading rumors about one of the characters; causing physical harm to other characters; threatening to withdraw and stop friendship; causing envy in others; threatening others physically; blaming others although they do not deserve it; saying mean things; destroying the friendship between characters in the program; stealing things; over-criticizing, even without reason; cursing or insulting others; being sarcastic; being destructive; discovering secrets of others; not letting others express their opinions; arguing with others in the program; damaging someone else's property; starting fights.

c. Index of criticism of the character, 15 items; average $=3.16$, standard deviation $=1.38$, reliability (Cronbach's $\alpha)=0.85$. Respondents were asked to indicate the most suitable answer, such as: I think that the behavior of the characters in the TV program I like shows how to behave with friends; I would like to participate in the television show I love; I am critical of the television program I love; I think that whatever happens in the television program I like is very similar to what is happening in real life; I often think that the characters in the program should have behaved differently; I have a lot of criticism for the way the characters in my favorite TV show behave; in my opinion, one can learn a lot about real life from the TV program that I love; How much do you enjoy watching the TV show you love? How much do you prefer to watch TV shows that you like over other programs? How much do you prefer to watch the TV show you love over other types of entertainment? How often do you watch the TV show you love instead of performing other tasks you have to do (homework, housework)? How much do you identify with at least one of the characters on the TV show you love? The characters on the TV show I love behave like my friends; When the characters on the TV show that I love are sad, I'm also sad; When the characters on the TV show that I love are excited, I'm also excited.

- Questionnaire for measuring aggressive tendencies (FOA), based on the questionnaires of Verona, Sadeh, Case, Reed, and Bhattacharjee (2008). The questionnaire included 10 items reported by the child relating to the extent of the child's involvement in various types of aggression. Items were rated on a 6-point scale, ranging from $1=$ not at all to $6=$ yes, quite); average $=2.51$, standard deviation $=1.24$, reliability $($ Cronbach $\alpha)=0.87$. For example: When I'm nervous or angry at other people, I start hitting; I threaten them physically; I hit, kick, or push others; I don't let them express their opinions; I come down on them; I say mean things to them; I ruin their friendship with other people; I worry that they won't be in my group of friends; I'm friendly with someone else; I don't help them when they need my help.

- Recreational habits questionnaire based on Ofcom: Office of Communications (2010) and Livingstone et al. (2012). Respondents were asked to specify how much time they devote to different types of activities throughout the week. Their answers were given relative to an ordinal answer scale, which for the purpose of analysis was converted into an ordinal answer scale in which the responses represent the middle of the appropriate categories. Viewing habits were rated at a total of 1 to 5 hours, 6-10 hours, 11-15 hours, over 15 hours; 9 items: how many hours per week you spend usually: with friends after school; in after-school classes; watching TV; watching YouTube; watching movies and shows on your computer; surfing the Internet; using social networks; reading a book; talking on the phone. For the purpose of analysis, the types of recreation of the respondents were divided into three categories, which were calculated as the average of the hours in each type of recreation.

Table 2. Characteristics of identification variables and recreational habits (number of hours per week)

\begin{tabular}{cccc}
\hline Recreational habits & $M$ & $S D$ & Cronbach's $\alpha$ \\
\hline Face-to-face encounters with others & 4.79 & 3.85 & .593 \\
Digital media & 6.09 & 3.97 & .849 \\
Reading books & 2.47 & 3.08 & \\
\hline
\end{tabular}

- Open questions: Which TV program do you like to watch? What do you like about this program? What is your favorite character? Do you watch scary TV shows? Do these programs cause you nightmares and fears? What 
makes you keep watching scary programs? Do you feel that the characters and plot in the shows you are watching are life-like, realistic? List the names of the scary programs you are watching.

- Personal interviews: A total of 45 children and adolescents were interviewed. Interviewees were asked questions to clarify the findings, to help us understand the reasons behind the findings. The semi-structured interviews covered all the subjects included in the research topics, but the order of questions was determined by the dynamics of the interview. The interviewees wanted to share events they lived through, both positive and negative experiences, and some of them provided detailed descriptions.

\section{Findings}

Below we present the findings on the correlations between media usage patterns, positive and negative identification with the characters, criticism of the characters, self-image and sense of anger, background characteristics, entertainment habits, and the use of media in all its forms. The preference for types of TV programming is a main factor in interest in programs and in children's and adolescents' patterns of viewing frightening programs.

\section{Favorite TV Genre}

The participants were asked to indicate which TV genre they liked to watch. Figure 1 presents the rates of viewing of the various programs by children and adolescents, according to the type of programs that the participants noted.

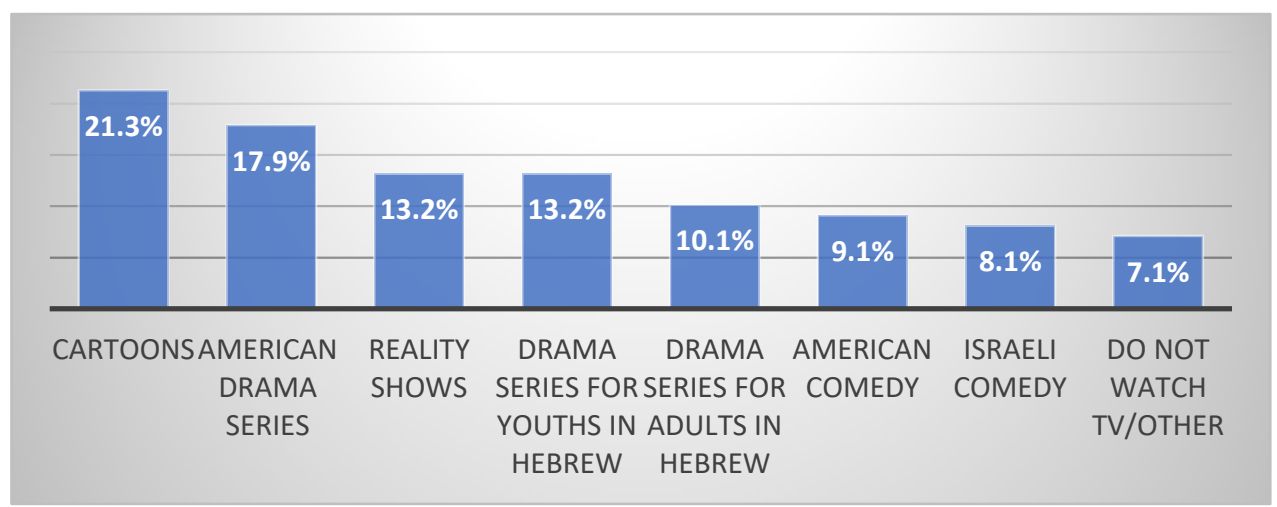

Figure 1. The rates of viewing of various programs by children and adolescents by type of program

Figure 1 shows that the most watched programs are cartoon series (21.3\%), followed by American drama series (about $18 \%)$. About $13 \%$ of respondents watch reality shows and drama series in Hebrew.

\section{Main Factors Affecting Interest in TV Programs}

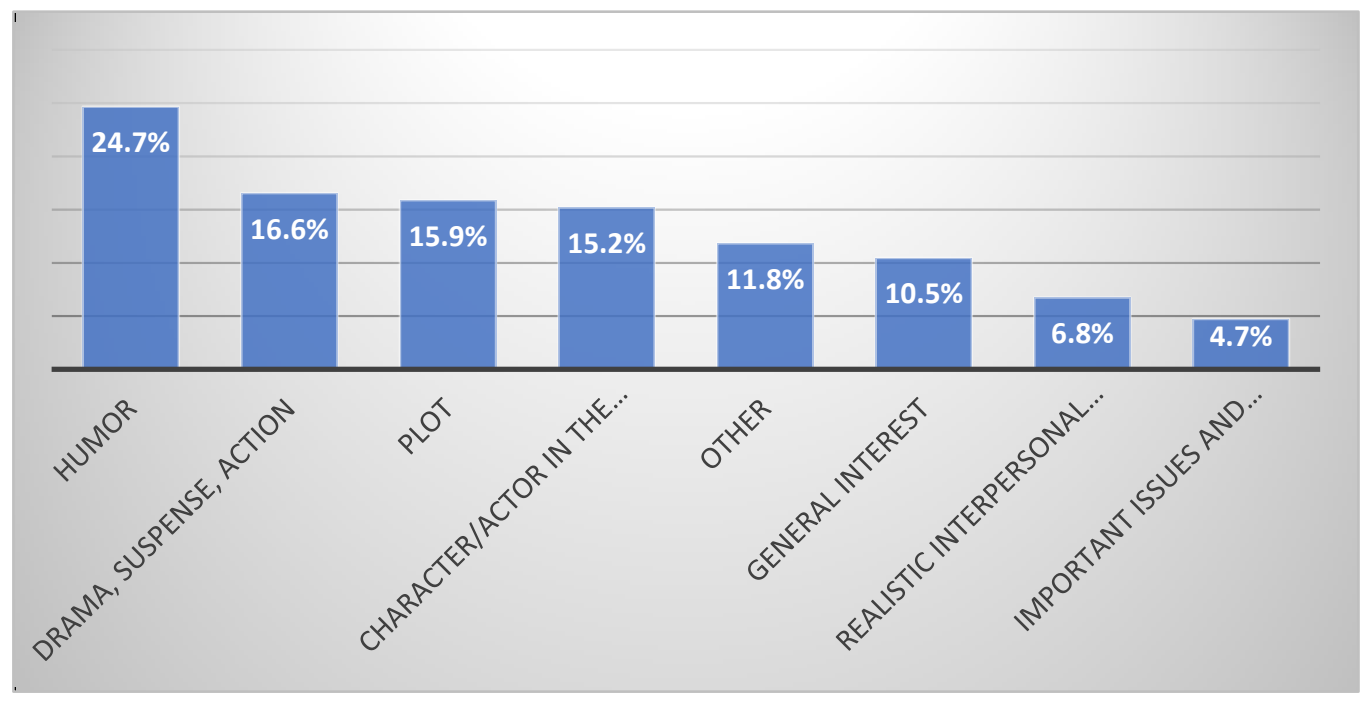

Figure 2. Rates of children's and adolescents' interest in programs, by reason of interest

Figure 2 shows that $16 \%$ of respondents indicated that the plot was what makes them interested in the programs they like to watch; $15 \%$ watch programs because of interest in a character/actor; $17 \%$ watch programs because of interest in drama, suspense, or action; $25 \%$ watch the show because of its humor - this is the most significant factor. 


\section{Watching Scary Programs}

The patterns of watching scary programs were examined based on qualitative analysis of the responses. Respondents' answers to the question "Do you usually watch scary TV shows? Explain" revealed four levels of reference that distinguish between respondents who indicated "not at all" (57.9\%) and those who do not normally watch such programs (6.9\%), watch sometimes (7.6\%), or always (27.6\%). For the purpose of this analysis, however, the responses were grouped into two categories that distinguish between those who watch scary movies $(42.1 \%)$ and those who do not (57.9\%).

\section{Nightmares and the Perception of Characters and Plot as Realistic in Scary Shows}

The qualitative answers of the participants to the question "Are these programs causing you nightmares and fears? Explain" were coded into three levels. The survey found that $76.4 \%$ reported that watching scary programs did not cause them nightmares or fears, $4.4 \%$ reported that this type of programming sometimes caused nightmares and fears, and $19.2 \%$ reported that they regularly had nightmares or fears as a result of such viewing. For the purpose of analysis, the responses were grouped into two categories that distinguish between those for whom watching scary films causes nightmares and fears $(23.6 \%)$ and those for whom it does not $(76.4 \%)$.

Similarly, the participants' qualitative responses to the question "Do you feel that the characters and plot in the programs you are watching are real, realistic?" were coded into three levels, which distinguish between participants who do not believe that the characters and plot are realistic (45.2\%); those who believe that the characters and the plot are partially realistic (21.2\%); and those who completely believe that the characters and the plot are realistic (33.6\%). For the purpose of analysis, the responses were grouped into two categories that distinguish between those who believe that the characters and the plot in the scary programs are realistic (54.8\%) and those who do not (45.2\%).

\section{Connections Between Variables}

A multivariable regression analysis (MANOVA) was conducted to examine the relationship between dependent and explanatory variables: self-image, negative and positive identification with the characters, criticism of the characters, self-image and anger response to background characteristics, habits, preferences and types of programs, and the main factor for interest in programs, and viewing patterns of scary shows (Table 3). The reference group comprises girls with a strong socioeconomic background.

Table 3. Multivariable regression (MANOVA) of self-image, negative and positive identification with the characters, criticism of the characters, self-image and anger response to background characteristics, habits, preferences and types of programs, main factor for interest in programs, and viewing patterns of scary shows

\begin{tabular}{|c|c|c|c|c|c|c|c|c|c|c|c|}
\hline \multirow{3}{*}{\multicolumn{2}{|c|}{ Exploratory variables }} & \multicolumn{10}{|c|}{ Dependent variables } \\
\hline & & \multicolumn{2}{|c|}{$\begin{array}{c}\text { Negative } \\
\text { identification }\end{array}$} & \multicolumn{2}{|c|}{$\begin{array}{c}\text { Positive } \\
\text { identification }\end{array}$} & \multicolumn{2}{|c|}{$\begin{array}{l}\text { Criticism of } \\
\text { characters }\end{array}$} & \multicolumn{2}{|c|}{ Self-image } & \multicolumn{2}{|c|}{$\begin{array}{c}\text { Reaction in } \\
\text { situations of } \\
\text { anger FOA }\end{array}$} \\
\hline & & B & $\eta^{2}$ & B & $\eta^{2}$ & B & $\eta^{2}$ & B & $\eta^{2}$ & B & $\eta^{2}$ \\
\hline \multirow{7}{*}{$\begin{array}{l}\text { Backgro } \\
\text { und }\end{array}$} & Cross-section & $\begin{array}{c}3.87 * \\
*\end{array}$ & 0.07 & 0.68 & 0.00 & $\begin{array}{l}4.38^{*} \\
*\end{array}$ & 0.10 & $\begin{array}{c}3.47 * \\
*\end{array}$ & 0.44 & $2.20^{*}$ & 0.03 \\
\hline & $\begin{array}{l}\text { Children with low/ } \\
\text { average socioeconomic } \\
\text { background }\end{array}$ & $1.40^{*}$ & 0.03 & $1.16^{*}$ & 0.03 & 0.21 & 0.00 & -0.18 & 0.01 & 0.95 & 0.02 \\
\hline & $\begin{array}{l}\text { Children with strong } \\
\text { socioeconomic } \\
\text { background }\end{array}$ & $\begin{array}{c}1.53 * \\
*\end{array}$ & 0.04 & -0.10 & 0.00 & $1.29 *$ & 0.03 & 0.00 & 0.00 & $1.13^{*}$ & 0.03 \\
\hline & $\begin{array}{l}\text { Adolescents with low / } \\
\text { average socioeconomic } \\
\text { background }\end{array}$ & 0.23 & 0.00 & $\begin{array}{c}1.23 * \\
*\end{array}$ & 0.07 & 0.06 & 0.00 & $\begin{array}{l}-0.49 * \\
*\end{array}$ & 0.09 & $\begin{array}{c}0.93^{*} \\
*\end{array}$ & 0.04 \\
\hline & $\begin{array}{l}\text { Adolescents with strong } \\
\text { socioeconomic } \\
\text { background }\end{array}$ & $0.86^{*}$ & 0.02 & 0.36 & 0.01 & -0.27 & 0.00 & -0.05 & 0.00 & -0.42 & 0.01 \\
\hline & $\begin{array}{l}\text { Children with low/ } \\
\text { average socioeconomic } \\
\text { background }\end{array}$ & $1.00 *$ & 0.02 & $0.92 *$ & 0.03 & 0.44 & 0.00 & -0.12 & 0.00 & 0.81 & 0.02 \\
\hline & $\begin{array}{l}\text { Children with strong } \\
\text { socioeconomic }\end{array}$ & 0.37 & 0.00 & $\begin{array}{c}1.94 * \\
*\end{array}$ & 0.09 & $\begin{array}{c}1.47 * \\
*\end{array}$ & 0.04 & -0.24 & 0.01 & $\begin{array}{c}1.24 * \\
*\end{array}$ & 0.04 \\
\hline
\end{tabular}




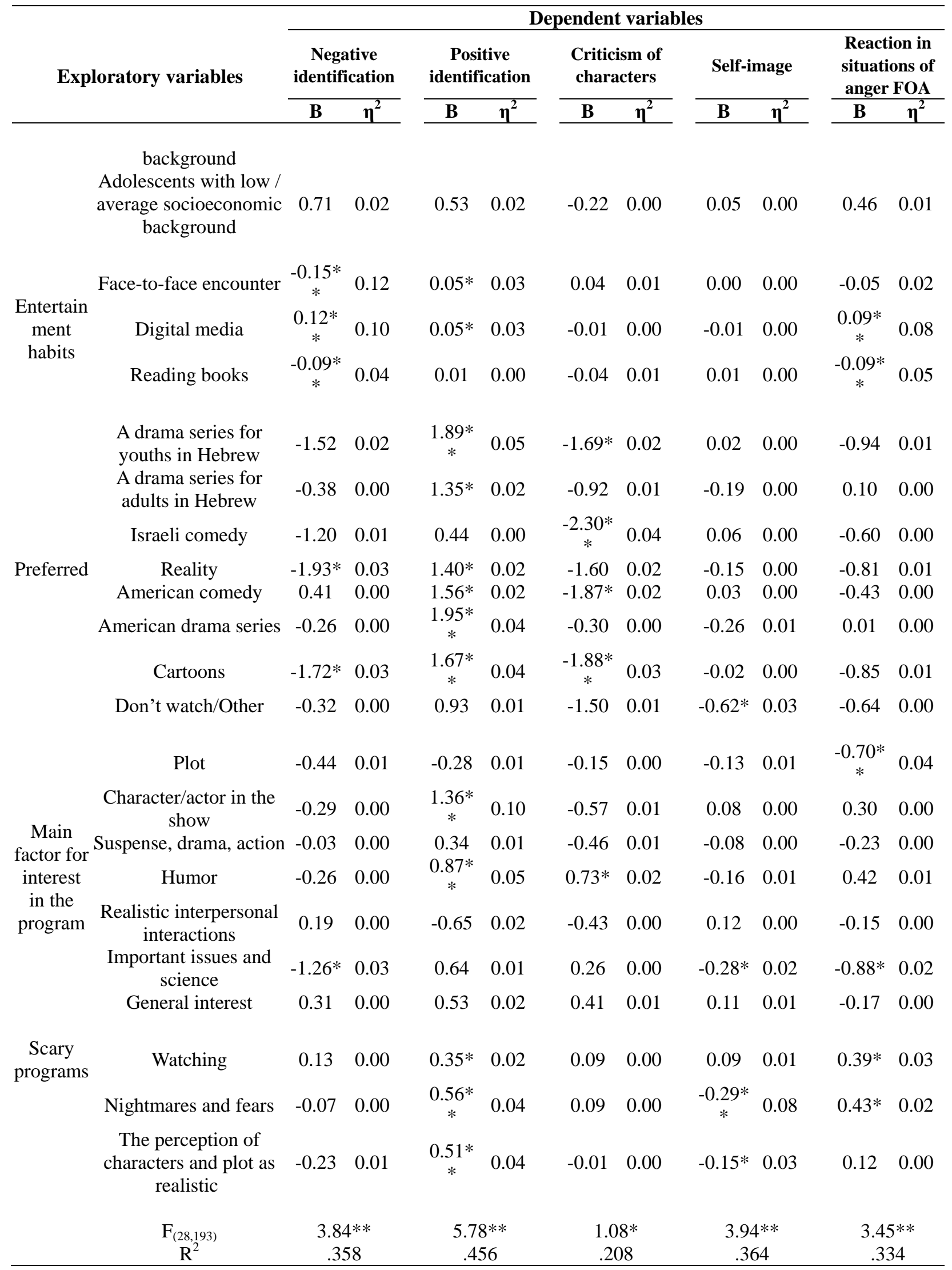

$* * \mathrm{p}<.01, * \mathrm{p}<.01$ 
Table 3 reveals the following findings:

Negative identification with the characters:

- The model is significant and explains about $36 \%$ of the variance of the variable.

- Children (regardless of their socioeconomic situation), boys from a strong socioeconomic background, and girls with a low/average socioeconomic background demonstrated higher levels of negative identification with the characters than did adolescent girls from a strong socioeconomic background.

- Negative identification decreases with the increase in frequency of meeting with friends and with increased reading of books by respondents. At the same time, the negative identification with the characters increases with the amount of time devoted to digital communication.

- Negative identification with the characters is lower in respondents who like to watch reality shows and cartoon series.

- Negative identification is lower in respondents who are interested in current affairs and science.

- Viewing scary programs, and respectively, reports of nightmares and fears, and of perception of characters and plots as realistic, do not affect the degree of negative identification with the characters.

Positive identification and perception of the characters' contribution:

- The model is significant and explains about $46 \%$ of the variance of the variable.

- Children from low/average socioeconomic backgrounds, boys from low socioeconomic backgrounds, and girls (regardless of their socioeconomic background) showed a higher level of positive identification with the characters in the show than did girls from strong socioeconomic background.

- Positive identification increases with the amount of time spent on meeting friends and on digital communication.

- The level of positive identification is higher for respondents who like to watch youth drama series in Hebrew, adult drama series in Hebrew, reality shows, American comedies, American drama series, and cartoons.

- Positive identification with the characters is higher for respondents who are interested in the characters/actors in the show and for respondents who are interested in humor.

- The level of positive identification with the characters is higher for respondents who watch scary programs, and it is higher for those who suffer from nightmares and fears and for those who perceive the characters and plots as realistic.

Criticism of the characters:

- The model is significant and explains about $21 \%$ of the variance of the variable.

- Boys and girls from a strong socioeconomic background demonstrated a higher level of criticism of the characters than did adolescent girls from a strong socioeconomic background.

- The level of criticism does not depend on the respondents' habits.

- The level of criticism of the characters is lower for those who prefer to watch drama series for youths in Hebrew, Israeli comedies, American comedies, and cartoons.

- The level of criticism of the characters is higher for those whose main concern is humor.

- The level of criticism of the characters is not affected by watching scary programs, by suffering from nightmares and fears, or by a realistic perception of the plots and characters.

Self-esteem:

- The model is significant and explains about $36 \%$ of the variance of the variable.

- $\quad$ Adolescent boys from a low/average socioeconomic background demonstrated lower self-image than did adolescent girls from a strong socioeconomic background.

- $\quad$ Self-image does not depend on the habits of the respondents.

- $\quad$ Program viewing preferences did not affect self-image, except that the self-image of respondents who do not watch television was found to be lower.

- The self-image of respondents who are interested in current events and science is lower. 
- The self-image of respondents who suffer from nightmares and fears is lower, as is the self-image of those who perceive the characters and plots in scary shows as realistic.

Reactions in a state of anger:

- The model is significant and explains about $33 \%$ of the variance of the variable.

- $\quad$ Children from a strong socioeconomic background and adolescent boys (regardless of their socioeconomic background) showed more angry reactions than did adolescent girls coming from a strong socioeconomic background.

- There quantity of angry reactions increases with the increase in the use of digital communication, and there are fewer angry reactions as the time devoted to reading increases.

- $\quad$ Program viewing preferences did not affect angry reactions.

- $\quad$ There are fewer angry reactions by respondents interested in the plot and by those interested in current affairs and science.

- $\quad$ There are more angry reactions by respondents who watch scary programs and by those who reported suffering from nightmares and fears.

Table 4. Correlations

\begin{tabular}{ccccc}
\hline & $\begin{array}{c}\text { Negative } \\
\text { identification } \\
\text { with TV } \\
\text { characters }\end{array}$ & $\begin{array}{c}\text { Identification } \\
\text { and positive } \\
\text { contribution of } \\
\text { a TV character }\end{array}$ & $\begin{array}{c}\text { Criticism of a } \\
\text { TVaracter }\end{array}$ & $\begin{array}{c}\text { Self-image } \\
\text { Reaction in a } \\
\text { state of anger } \\
\text { FOA }\end{array}$ \\
\hline $\begin{array}{c}\text { Negative identification with TV } \\
\text { characters }\end{array}$ & 1 & & & \\
$\begin{array}{c}\text { Identification and positive } \\
\text { contribution of a TV character } \\
\text { Criticism of a TV character }\end{array}$ & $-.196^{* *}$ & 1 & 1 & 1 \\
$\begin{array}{c}\text { Self-image } \\
\text { Reaction in a state of anger FOA }\end{array}$ & $-322^{* *}$ & 0.095 & -0.073 & -0.091 \\
\hline
\end{tabular}

** $\mathrm{p}<.01, * \mathrm{p}<.01$

Table 4 reveals the following findings:

- $\quad$ There is a positive correlation between anger reaction and negative identification with the characters $(\mathrm{r}=.371$, $\mathrm{p}<.01)$, the level of positive identification with the characters $(r=.259, \mathrm{p}<.01)$, and the level of criticism of the characters $(\mathrm{r}=.167, \mathrm{p}<.01)$.

- No significant correlations were found between the self-image and other research variables.

\section{Discussion}

In this study we explored the connections between patterns of usage of various media, watching scary TV programs, identification with characters, and fears and nightmares as a result of watching the shows, in children and adolescents. The research question was: What characterizes the connections between patterns of use of various media, watching scary TV programs, identifying with characters, and fears and nightmares resulting from watching, in children and adolescents?

Instructive findings concern the connections between patterns of usage of the various media, negative and positive identification with the characters, criticism of the characters, self-image, and feelings of anger, in relation to the background characteristics, entertainment habits, and the usage of various media on one hand, and the preference for types of TV shows and the main factor affecting the interest in programs and patterns of viewing scary shows by children and adolescents on the other.

Negative identification with the characters. Negative identification refers to violent behavior of the character, damage to other characters, threats, etc. We found that negative identification with the characters is higher in children than in adolescents. The negative identification with the characters increases with the amount of time devoted to digital communication. At the same time, the negative identification decreases as the frequency of meetings with friends and the time devoted to reading books increase. The findings revealed that the negative identification is lower in respondents who are interested in current affairs and in science. The findings of this study corroborate previous findings (Arifinda $\&$ Hastuti, 2016; Lopez et al., 2006) that have reported on the negative effect of negative identification with TV characters, particularly on children and adolescents 
(Anderson \& Bushman, 2001; Boxer et al., 2009; Martins \& Wilson, 2012; Selah-Shayowits, 2006). Based on the findings of this and previous studies, it is recommended to encourage children to participate in social gatherings and to watch television programs without extensive violence.

Positive identification and perception of the characters' contribution. Positive identification refers to the desire of the viewer to be like the character, to be a friend of the character, when the viewer feels that the character is sociable, and that the character's behavior contributes to a positive atmosphere in the show. Positive identification increases with the amount of time spent meeting with friends. Respondents who like to watch drama series for youths, adult drama series, reality shows, comedies, humor, and cartoons demonstrated a higher level of positive identification. The level of positive identification with the characters was higher in respondents who watch scary shows, in those who suffer from nightmares and fears, and in those who perceive the characters and plots as realistic. Researchers (Bandura, 1971, 1986, 2001; Cole \& Leeds, 1999; Hough \& Erwin, 2010; Livingston \& Das, 2010; Morgan \& Shanahan, 2010; Rideout et al., 2010; Rome, 2018; Vandewater et al., 2006; Wilson, 2011; Zilka, 2014) found that television presents a wide variety of role models and offers children and adolescents an opportunity to check and compare alternate identities in their imagination. In this way, it exposes children to a variety of characters as possible role models whom they would be unlikely to meet face to face. The mechanism of identification with TV characters is part of the process in which children can examine the behaviors of characters, choose behaviors, and integrate them into their lives.

Criticism of the characters. The level of criticism of the characters was found to be lower in respondents who prefer to watch drama series for youths, comedies, and cartoons. The level of criticism of the characters was not affected by watching scary shows, by nightmares or fears, or by a realistic perception of the plots and characters.

Nightmares and fears. We found that about a quarter of the respondents reported that viewing scary shows caused them nightmares and fears. It transpired that interest in suspense, drama, and action programs increases the chance of nightmares and fears after watching scary shows. In general, the percentage of girls to whom scary shows cause nightmares and fears was higher than that of boys, and higher among children than among adolescents. The self-image of those suffering from nightmares and fears was lower than that of the others, as was the self-image of respondents who perceive the characters and plots in scary shows as realistic. We also found that angry reactions were more common in those who watched scary shows and in those who had nightmares and fears. A positive correlation was revealed between anger reaction and the level of negative identification with the characters $(r=.371, p<.01)$, the positive level of positive identification with them $(r=.259, \mathrm{p}<.01)$, and the level of criticism of the characters $(r=.167, p<.01)$. About one-third of respondents who watch scary programs continue to watch out of interest, and a similar percentage watch them because of the suspense and action associated with these programs, or because of the fun and pleasure involved in watching. Thirteen percent of the respondents explained that they continue to watch because of fear, and about $7 \%$ do not continue (or at least prefer not to continue watching). We found a connection between fears and nightmares, and low self-image and anger, which affects the mental wellbeing of the children and adolescents. Researchers (Bandura, 1965; Cline et al., 1973; Huesmann et al., 2003; Millwood-Hargrave \& Livingstone, 2006, 2009) found that watching violence increases the fears and nightmares of the viewers and may distort the perception of reality in children and adolescents. It should be noted, however, that the choice of TV characters to identify with is not only a function of the characters' traits but also of viewers'. Eyal and Rubin (2010) found that violent adolescents tended to identify with characters perceived as violent. The identification of children with TV characters does not occur in a social void; television programs are part of the life environment of children and adolescents, and their influence on the shaping personality and identity of the latter is affected by other environmental factors.

\section{Implications}

Identification with TV characters enables learning about negative and positive behaviors. It should be remembered that not every character causes identification, and without identification, the chance of adoption and imitation of the character's behavior is small. The choice of identification with television characters is not only a function of character traits but also of the characteristics of the viewer of the show. Apart from the immediate behavioral effects of identification with television characters, watching programs involves psychological processes that have immediate and long-term effects on identity formation.

\section{Future Studies}

In this study we explored the connections between patterns of usage of a variety of media and the degree of identification with characters in the show, and the fears and nightmares resulting from watching these programs. More studies should examine the relationship between TV viewing and fears and nightmares in children and adolescents, because fears and nightmares affect their wellbeing. 


\section{References}

Adler, P. A., \& Adler, P. (2008). Of Rhetoric and Representation: The Four Faces of Ethnography. The Quarterly Sociological, 49(1), 1-30. https://doi.org/10.1111/j.1533-8525.2007.00104.x

Anderson, C. A., \& Bushman, B. J. (2001). Effects of violent video games on aggressive behavior, aggressive cognition, aggressive affect, physiological arousal and prosocial behavior: A meta-analytic review of the scientific literature. Psychological Science, 12(5), 353-359. https://doi.org/10.1111/1467-9280.00366

Arifinda, N. A., \& Hastuti, D. (2016). The Influence of Television Access and Impersonating Violent Contents to Bullying Behavior on Elementary School Children. Journal of Child Development Studies, 1(1), 1-12. https://doi.org/10.29244/jcds.1.01.1-12

Atkinson, E., \& Delamont, S. (2006). In the roiling smoke: qualitative inquiry and contested fields. International Journal of Qualitative Studies in Education, 19(6), 747-755. https://doi.org/10.1080/09518390600975974

Atwal, K., Millwood, H. A., Sancho, J., Agyeman, L., \& Karet, N. (2003). What children watch: Analysis of children's programming provisions between 1997-2001. London: BSC/ITC.

Bandura, A. (1965). Influence of models' reinforcement contingencies on the acquisition of imitative responses. Journal of Personality and Social Psychology, 1(6), 589-595. https://doi.org/10.1037/h0022070

Bandura, A. (1986). Social foundations of thought and action: A social cognitive theory .Englewood Cliffs, NJ: Prentice Hall.

Bandura, A. (2001). Social Cognitive theory of mass communication. Media Psychology, 3, 265-299. https://doi.org/10.1207/S1532785XMEP0303_03

Bandura, A. (1971). Principles of behavior modification. London: Holt.

Beavers, A. S., Lounsbury, J. W., Richards, J. K., Huck, S. W., Skolits, G. J., \& Esquivel, S. L. (2013). Practical considerations for using exploratory factor analysis in educational research. Practical assessment, research \& evaluation, 18.

Block, M. E. (1995). Development and validation of the Children's Attitudes toward Integrated Physical Education-Revised (CAIPE-R) Inventory. Adapted Physical Activity Quarterly, 12, 60-77. https://doi.org/10.1123/apaq.12.1.60

Boxer, P., Huesmann, L. R., Bushman, B. J., O’Brien, M., \& Moceri, D. (2009). The role of violent media preference in cumulative developmental risk for violence and general aggression. Journal of Youth and Adolescence, 38(3), 417-428. https://doi.org/10.1007/s10964-008-9335-2

Brown, J. D. (2009). Choosing the Right Number of Components or Factors in PCA and EFA. JALT Testing \& Evaluation SIG Newsletter, 13(1), 19-23.

Byron, T. (2008). Safer children in a digital world: The report of the Byron Review. Retrieved from: http://webarchive.nationalarchives.gov.uk/20130401151715/http://www.education.gov.uk/publications/eOrderingD ownload/DCSF-00334-2008.pdf

Cline, V. B., Croft, R. G., \& Courier, S. (1973). Desensitization of children to television violence. Personality and Social Psychology, 27, 360-365. https://doi.org/10.1037/h0034945

Cole, T., \& Leets, L. (1999). Attachment style and intimate television viewing: Insecurely forming relationships in a para-social way. Journal of Social and Personal Relationships, 16(4), 495-511. https://doi.org/10.1177/0265407599164005

Comstock, G. A., \& Scharrer, E. (2007). Media and the American Child. Academic Press, Amsterdam; Boston.

Eyal, K., \& Rubin, A. (2010). Viewer Aggression and Homophily, Identification, and Parasocial Relationships With Television Characters. Journal of Broadcasting \& Electronic Media, 47(1), 77-98. https://doi.org/10.1207/s15506878jobem4701_5

Gatfield, L., \& Millwood-Hargrave, A. (2003). Dramatic Licence - Fact or Fiction? London: Broadcasting Standards Commission.

Hammersley, M. (2008). Questioning Qualitative Research: Critical Essays. London, UK: Sage. https://doi.org/10.4135/9780857024565

Holbert, R. L., \& Stephenson, M. T. (2003). The Importance of Indirect Effects in Media Effects Research: Testing for Mediation in Structural Equation Modeling. Journal of Broadcasting and Electronic Media, 47(4), 556-572. 
https://doi.org/10.1207/s15506878jobem4704_5

Hough, K. J., \& Erwin, P. G. (2010). Children's attitudes toward violence on television. The Journal of Psychology, 131(4), 411-415. https://doi.org/10.1080/00223989709603528

http://www.ofcom.org.uk/advice/media_literacy/medlitpub/medlitpubrss/children/children.pdf

Huesmann, L. R., Moise-Titus, J., Podolski, C., \& Eron, L. D. (2003). Longitudinal relations between children's exposure to TV violence and their aggressive and violent behavior in young adulthood: 1977-1992. Developmental Psychology, 39(2), 201-221. https://doi.org/10.1037/0012-1649.39.2.201

Leung, L. (2013). Generational differences in content generation in social media: The roles of the gratifications sought and of narcissism. Computers in Human Behavior, 29(3), 997-1006. https://doi.org/10.1016/j.chb.2012.12.028

Livingstone, S. (2007). Evaluating the online risks for children in Europe. Telos, 73, 52-69.

Livingstone, S. (2008). Taking risky opportunities in youthful content creation: teenagers' use of social networking sites for intimacy, privacy and self-expression. New Media \& Society, 10(3), 459-477. https://doi.org/10.1177/1461444808089415

Livingstone, S., \& Das, R. (2010). Media, communication and information technologies in the European family: A report for the Family Platform project, funded by the European Commission. London: LSE.

Livingstone, S., Haddon, L., \& Görzig, A. (Eds.). (2012). Children, risk and safety on the internet: Research and policy challenges in comparative perspective. Marston Books, Bristol, UK: Policy Press. https://doi.org/10.1332/policypress/9781847428837.001.0001

Livingstone, S., Mascheroni, G., Ólafsson, K., \& Haddon, L. (2014). Children's online risks and opportunities: Comparative findings from EU kids Online and Net Children Go Mobile. LSE, London: EU Kids Online.

Lopez, A. D., Mathers, C. D., Ezzati, M., Jamison, D. T., \& Murray, C. J. (2006). Global and regional burden of disease and risk factors, 2001: systematic analysis of population health data. Lancet, 367. https://doi.org/10.1016/S0140-6736(06)68770-9c

Martins, N., \& Wilson, B. J. (2012). Social aggression on television and its relationship to children's aggression in the classroom. Human Communication Research, 38(1), 48-71. https://doi.org/10.1111/j.1468-2958.2011.01417.x

McQuail, D. (2010). Mass communication theory: An introduction. London: Sage.

Millwood-Hargrave, A. (2007). Issues facing broadcast regulation. Broadcasting Standards Authority, London.

Millwood-Hargrave, A., \& Livingstone, S. (2006). Harm and Offence in Media Content: A review of the empirical literature. Bristol: Intellect Press.

Millwood-Hargrave, A., \& Livingstone, S. (2009). Harm and offence in media content: a review of the evidence (2nd ed). Intellect, Bristol, UK. ISBN 9781841502380

Morgan, M., \& Shanahan, J. (2010). The state of cultivation. Journal of Broadcasting \& Electronic Media, 54(2), 337-355. https://doi.org/10.1080/08838151003735018

Ofcom - Office of Communications. (2006), Media Literacy Audit: Report on media literacy amongst children. London: Ofcom. Available at

Ofcom - Office of Communications. (2010). UK adults' media literacy. Retrieved from http://stakeholders.ofcom.org.uk/binaries/research/media-literacy/adults-media-literacy.pdf

Rideout, V. J., Foehr, U. G., \& Roberts, D. F. (2010). Generation M2: Media in the lives of 8-18 year-olds. Menlo Park, CA: Kaiser Family Foundation.

Rogers, C. R. (1967). On Becoming a Person: a Therapist's View of Psychotherapy. London: Constable.

Selah-Shayovits, R. (2006). Adolescent preferences for violence in television shows and music video clips. International Journal of Adolescence and Youth, 13, 99-112. https://doi.org/10.1080/02673843.2006.9747968

Taylor, P., \& Kitter, S. (2010). Millennials: A portrait of generation next. Retrieved from http://pewsocialtrends.org/assets/pdf/millennials-confident-connected-open-to-change.pdf

Vandewater, E. A., Bickham, D. S., \& Lee, J. H. (2006). Time well spent? Relating television use to children's free-time activities. Pediatrics, 117(2), 181-191. https://doi.org/10.1542/peds.2005-0812 
Verona, E., Sadeh, N., Case, S. M., Reed, A., II, \& Bhattacharjee, A. (2008). Self-reported use of different forms of aggression in late adolescence and emerging adulthood. Assessment, 15, 493-510. https://doi.org/10.1177/1073191108318250

West, R., \& Turner, L. (2007). Introducing communication theory. New York: McGraw Hill.

Wilson, B. (2011). Media violence and aggression in youth. In B. Wilson \& S. Calvert (Eds), The handbook of children, media and development (pp. 237-267). OxfordL Wiley-Blackwell.

Zilka, C. G. (2014). Empowering educators \& mentors in the social media age - The Three Element Way. Tel Aviv: Bitan-Galim (Hebrew).

Zilka, C. G. (2016a). Do online friendships contribute to the social development of children and teenagers? The bright side of the picture. International Journal of Humanities and Social Science (IJHSS), 6(7). http://www.ijhssnet.com/

Zilka, C. G. (2017). The Elements Way: Empowering parents, educators, and mentors in the age of new media. Issues in Informing Science and Information Technology, 14, 101-119. https://doi.org/10.28945/3702

Zilka, C. G. (2018a). eSafety and sharing habits with family and friends among children and youths. Child and Adolescent Social Work Journal. https://doi.org/10.1007/s10560-018-0573-1

Zilka, C. G. (2018b). Medium preferences of children and adolescents for content distributed by the media. Interchange (INCH), 49(4), 457-476. https://doi.org/10.1007/s10780-018-9337-2

Zilka, C. G. (2018c). Why do children and adolescents consume so much media? An examination based on self-determination theory. Global Media Journal, 16(30), 111-121.

Zilka, C. G., \& Romi, S. (2018). Television Viewing Habits and Identification with Characters Seen among At-risk and Normative Children and Youth. International Journal of Child, Youth and Family Studies, 9(3), 47-67. https://doi.org/10.18357/ijcyfs93201818276

Zilka, G. C. (2016b). Reducing the digital divide among children who received desktop or hybrid computers for the home. Journal of Information Technology Education: Research, 15, 233-251. https://doi.org/10.28945/3519

\section{Copyrights}

Copyright for this article is retained by the author(s), with first publication rights granted to the journal.

This is an open-access article distributed under the terms and conditions of the Creative Commons Attribution license (http://creativecommons.org/licenses/by/4.0/). 